\title{
Meiotic Chromosome Behavior and Capsule Setting in Doritaenopsis Hybrids
}

\author{
Pablo Bolaños-Villegas \\ Department of Tropical Agriculture and International Cooperation, National Pingtung University of \\ Science and Technology, \#1 Hsue Fu Road, Neipu, Pingtung, 91201, Taiwan, Republic of China \\ Shih-Wen Chin \\ Department of Plant Industry, National Pingtung University of Science and Technology, \#1 Hsue Fu \\ Road, Neipu, Pingtung, 91201, Taiwan, Republic of China \\ Fure-Chyi Chen ${ }^{1}$ \\ Department of Plant Industry, National Pingtung University of Science and Technology, \#1 Hsue Fu \\ Road, Neipu, Pingtung, 91201, Taiwan, Republic of China
}

\begin{abstract}
AdDITIONAL INDEX WORDS. pollen viability, orchid breeding
Abstract. The development of new cultivars in Doritaenopsis Guillaum. \& Lami orchids is often hindered by factors such as low seed count in hybrids. Cytological study may offer the ability to develop new hybrids by revealing cultivars with good chromosome pairing and high pollen viability, which are somewhat difficult to obtain under current breeding programs. Cross pollination, pollen viability, and chromosomal behavior during meiosis were analyzed to reveal the relation between seed fertility and capsule set in Doritaenopsis hybrids. The number of mature capsules harvested and their relative seed content were used as indices of crossing availability. The results of meiosis were evaluated according to pollen viability detected by fluorescein diacetate and quantification of sporad types by acid fuchsin staining. Chromosome number and pairing at meiosis were observed in root tips or in samples of pollen mother cells. A positive relation was found among high seed set, high frequency of viable tetrads, high degree of chromosome pairing, and low frequency of chromosomal aberrations such as inversions and translocations. On the basis of these factors, three types of hybrids could be distinguished. In type one hybrids, chromosomes paired as bivalents, pollen mother cells divided into tetrads, and capsule setting occurred after pollination of pollen acceptors. In type two hybrids, chromosomes remained mainly as univalents that developed into micromeiocytes, pollen mother cell division was disrupted, and seed recovery was low after pollination. Type three hybrids showed chromosomes paired mostly as multivalents, chromosome bridges, pollen mother cell division with massive failure, and little fertility. In Doritaenopsis orchids, high pollen viability and high fertility depends on a high frequency of normal tetrads, and low seed set in cross-pollination is predicted with micronuclei in the end products of meiosis. The occurrence of chromosomal aberrations may suggest a process of genome differentiation that could compromise breeding efforts if not taken into consideration.
\end{abstract}

In general, relatively little is known about the genetics of orchids because of the high cost of growing large populations of the plant, the relatively long growing cycles $(\approx 6$ years) to obtain two generations, and polyploidy in advanced-generation hybrids (Kamemoto et al., 1999). Differences in ploidy are a challenge to the development of new hybrids, and differences in chromosome number may prevent zygote development after pollination (Singh and Hymowitz, 1987). Chromosome doubling is often applied to produce new cultivars of orchids (Lin et al., 2001), as has been the case with colchicine-doubled amphidiploid cultivars in Dendrobium Swartz (Kamemoto et al., 1999).

In Phalaenopsis Blume, interspecific and intergeneric hybridization has long been used for breeding superior hybrids, but as for other orchid genera, very little is known about the genetics of the species (Kao et al., 2001). The information

Received for publication 6 Aug. 2007. Accepted for publication 6 Oct. 2007. This work was supported by grants from the Council of Agriculture, Taiwan (94AS-1.3.2-FD-Z3 and 95AS-1.3.2-FD-Z3), and by a grant for graduate study to the first author from the International Cooperation and Development Fund of Taiwan, Ministry of Foreign Affairs, Taiwan, Republic of China. We thank Dr. Mei-Chu Chung at the Institute or Plant and Microbial Biology, Academia Sinica, Taiwan, for her critical reading of the manuscript.

${ }^{1}$ Corresponding author. E-mail: fchen@mail.npust.edu.tw. currently available is chromosome number $(2 \mathrm{n}=2 \mathrm{x}=38)$, the karyotype of some representative species, the meiotic chromosome associations in several interspecic hybrids, and the genomic DNA content of several Phalaenopsis and Doritis Lindl. species (Arends, 1970; Lin et al., 2001).

Phalaenopsis species may have the same chromosome number, but genome sizes vary considerably (Kao et al., 2001). For instance, Shindo and Kamemoto (1963) compared the mean chromosome length of eight Phalaenopsis species and the closely related species Doritis pulcherrima Lindl. and they found a 2.8 -fold difference in chromosome length between species with the largest $(P$. violacea Witte) and the smallest chromosomes (P. amabilis Blume). Arends (1970) reported two groups in Phalaenopsis with high genome homology distinguished on the basis of chromosomal length at somatic metaphase, as well as chromosomal configurations in metaphase I of hybrids. The first group includes species with small chromosomes, such as $P$. amabilis, $P$. aphrodite Rchb. f., $P$. equestris (Schauer) Rchb. f., $P$. sanderiana Rchb. f., and P. stuartiana $\mathrm{Rchb}$. $\mathrm{f}$. The second group contains species with large chromosomes, such as $P$. amboinensis J. J. Sm. and P. mannii Rchb. f. Lin et al. (2001), using flow cytometry and southern hybridization techniques, concluded that chromosome size is 
Table 1. Genome constitution and cytological characteristics of nine Doritaenopsis hybrids.

\begin{tabular}{|c|c|c|c|}
\hline Hybrid $^{\mathrm{z}}$ & Parents (pollen receptor $\times$ pollen donor) ${ }^{\mathrm{x}}$ & $\begin{array}{l}\text { Length of } \\
\text { buds at } \\
\text { metaphase } \\
\text { I (mm) }\end{array}$ & $\begin{array}{l}\text { Length of } \\
\text { buds at } \\
\text { pachytene } \\
\text { (mm) }\end{array}$ \\
\hline Doritaenopsis Bin You Danseuse 'F574'y & Doritaenopsis Coral Gleam $\times$ Phalaenopsis Bright Danseuse & 14 & 12 \\
\hline Doritaenopsis Chian-Huey Red Rose 'F904' & Doritaenopsis Taisuco Firebird $\times$ Phalaenopsis New Cinderella & 9 & 7 \\
\hline Doritaenopsis Fuchsia Princess 'KHM648' & Doritaenopsis Coral Gleam $\times$ Doritis pulcherrima & 8 & 7 \\
\hline Doritaenopsis I-Hsin Purple Jewel & Doritaenopsis Purple Gem $\times$ Doritaenopsis Taisuco Jewel & 6 & 4 \\
\hline Doritaenopsis Jiuhbao Red Rose & $\begin{array}{l}\text { Doritaenopsis Taisuco Firebird } \times \text { Doritaenopsis } \\
\text { King Shiang's Rose }\end{array}$ & 8 & 7 \\
\hline Doritaenopsis Purple Gem & Doritis pulcherrima $\times$ Phalaenopsis equestris & 7 & 3.5 \\
\hline Doritaenopsis Sogo Gem 'F752' & Doritaenopsis Purple Gem $\times$ Doritaenopsis Minho Diamond & 16 & 11 \\
\hline Doritaenopsis Sogo Gem 'F859' & Doritaenopsis Purple Gem $\times$ Doritaenopsis Minho Diamond & 9 & $\mathrm{ND}^{\mathrm{w}}$ \\
\hline Doritaenopsis Sogo Gem 'F1082' & Doritaenopsis Purple Gem $\times$ Doritaenopsis Minho Diamond & 14 & ND \\
\hline
\end{tabular}

${ }^{\mathrm{z}}$ Hybrids are shown in alphabetical order.

${ }^{\mathrm{y}}$ Bracketed characters after grex indicate clonal name.

${ }^{x}$ Royal Horticultural Society, 2007.

wot determined.

Table 2. Seed set in several cross pollinations in Doritaenopsis and Phalaenopsis.

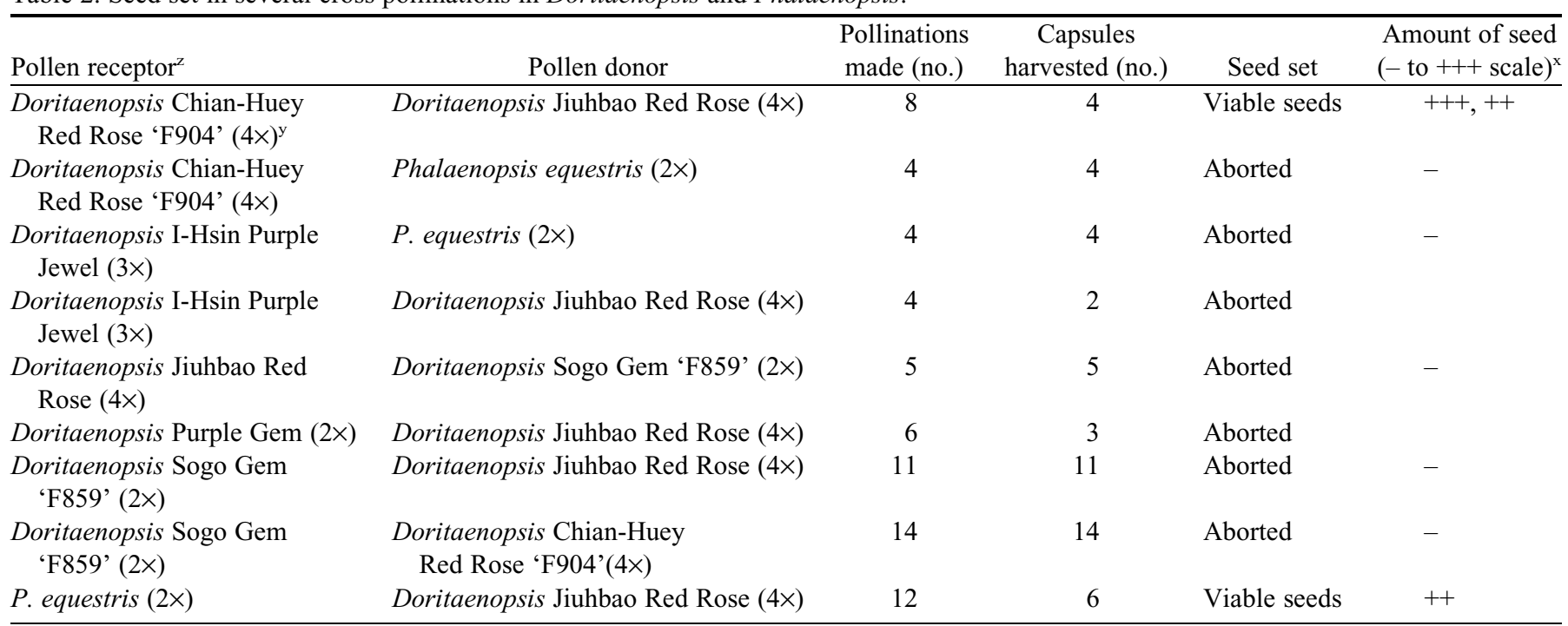

${ }^{\mathrm{z}}$ Pollen receptors are shown in alphabetical order.

yPloidy level, $2 x=$ diploid; $3 \times=$ triploid; $4 \times=$ tetraploid.

${ }^{\mathrm{x}}$ Seed content per capsule: lacking $(-)$, low $(+)$, abundant $(++)$, very abundant $(+++)$.

Table 3. Pollen viability as detected by fluorescein diacetate in species and hybrids of Doritaenopsis and Phalaenopsis.

\begin{tabular}{|c|c|}
\hline Hybrid/species ${ }^{z}$ & Viable pollen cells $[\text { mean } \pm \text { SD }(\%)]^{\mathrm{x}}$ \\
\hline Phalaenopsis equestris $^{\mathrm{y}}$ & $70.0 \pm 5.3$ \\
\hline Doritaenopsis Chian-Huey Red Rose 'F904' & $45.6 \pm 11.2$ \\
\hline Doritaenopsis Purple Gem & $41.4 \pm 8.3$ \\
\hline Doritaenopsis Sogo Gem 'F859' & $37.1 \pm 6.3$ \\
\hline Doritaenopsis Fuchsia Princess 'KHM648' & $36.7 \pm 3.1$ \\
\hline Doritaenopsis Bin You Danseuse 'F574' & $35.3 \pm 2.1$ \\
\hline Doritaenopsis Sogo Gem 'F1082' & $33.3 \pm 1.2$ \\
\hline Doritaenopsis Jiuhbao Red Rose & $33.0 \pm 12.6$ \\
\hline Doritaenopsis I-Hsin Purple Jewel & $31.3 \pm 12.2$ \\
\hline Doritaenopsis Sogo Gem 'F752' & $20.7 \pm 4.0$ \\
\hline
\end{tabular}

${ }^{\mathrm{z}}$ Hybrids are shown in descending order according to the frequency of viable cells observed.

y Phalaenopsis equestris was used as a standard for comparison of pollen division patterns.

${ }^{x}$ The total scoring number per individual sample is 1000 pollen mother cells; $n=3$. indeed related to repetitive genomic DNA content. Phalaenopsis species such as $P$. aphrodite, $P$. sanderiana, $P$. stuartiana, and $P$. lueddemaniana Rchb. f. with low DNA values have small-sized chromosomes; those with intermediate DNA values have middlesized chromosomes, and those with high DNA values, such as $P$. amboinensis and $D$. pulcherrima, have large-sized chromosomes.

The segregation of homologous pairs of chromosomes at meiotic anaphase I depends on prior pairing, synapsis, and recombination at earlier stages (Armstrong and Jones, 2003; Armstrong et al., 2001). Nevertheless, chromosome recognition and initial pairing in eukaryotes is not achieved by DNA-DNA interactions alone (Hiraoka, 1998; Schwarzacher, 
Table 4. Distribution of sporad types for several Doritaenopsis and Phalaenopsis orchids as seen by staining of pollen mother cells with lactophenol-acid fuchsin solution.

\begin{tabular}{|c|c|c|c|c|c|c|c|}
\hline \multirow[b]{2}{*}{ Hybrid/species ${ }^{\mathrm{z}}$} & \multicolumn{7}{|c|}{ Pollen mother cells (no.) $)^{\mathrm{y}}$} \\
\hline & Monad & Dyad & Triad & Tetrad & Tetrad $+1 \mathrm{mc}^{\mathrm{x}}$ & Tetrad $+2 \mathrm{mc}$ & Tetrad +3 or more $\mathrm{mc}$ \\
\hline Phalaenopsis equestris & 3 & 0 & 9 & 928 & 47 & 6 & 7 \\
\hline Doritaenopsis Chian-Huey Red Rose 'F904' & 12 & 7 & 18 & 835 & 108 & 17 & 3 \\
\hline Doritaenopsis Jiuhbao Red Rose & 19 & 27 & 50 & 607 & 226 & 43 & 28 \\
\hline Doritaenopsis Purple Gem & 34 & 5 & 6 & 568 & 306 & 52 & 29 \\
\hline Doritaenopsis Fuchsia Princess 'KHM648' & 5 & 63 & 140 & 516 & 201 & 33 & 42 \\
\hline Doritaenopsis Sogo Gem 'F1082' & 115 & 304 & 76 & 244 & 23 & 7 & 221 \\
\hline Doritaenopsis I-Hsin Purple Jewel & 12 & 56 & 99 & 225 & 200 & 129 & 279 \\
\hline Doritaenopsis Sogo Gem 'F752' & 127 & 241 & 219 & 182 & 53 & 18 & 56 \\
\hline Doritaenopsis Bin You Danseuse 'F574' & 241 & 63 & 56 & 56 & 18 & 17 & 590 \\
\hline Doritaenopsis Sogo Gem 'F859' & 15 & 16 & 12 & 15 & 5 & 30 & 907 \\
\hline
\end{tabular}

${ }^{\mathrm{z}}$ Hybrids and species are shown in descending order according to the frequency of tetrads observed.

${ }^{\mathrm{y}}$ The total scoring number per individual sample is 1000 pollen mother cells.

${ }^{\mathrm{x}} \mathrm{mc}=$ micronucleus.

2003), and factors such as chromosome morphology, specific sequence distribution, proteins bound to DNA, and chromatin condensation patterns may also be involved (Schwarzacher, 2003). Structurally tight heterochromatin might actually produce a selfcomplementary landscape that ensures partner recognition and alignment by "best-fit" mechanisms (Schwarzacher, 2003).

Heterochromatin is distinguished by its dense pattern of staining throughout the cell cycle and generally includes telomeric and pericentric regions. Heterochromatin is thought to be enriched for transposable elements and repetitive DNA; moreover, its condensed structure is repressive to transcription and recombination in this region or in nearby euchromatic, transcriptionally active areas (Huisinga et al., 2006). Heterochromatin is generally considered to replicate late in the S-phase, with two major subtypes known as facultative and constitutive heterochromatin. The term facultative refers to a reversible, epigenetically controlled state of chromatin. In contrast, in constitutive heterochromatin, the heterochromatic state is a heritable chromosomal trait (Pedrosa et al., 2001).

Phalaenopsis and Doritis species differ in the accumulation and distribution of heterochromatin on chromosomes, presumably as a result of the amplification of repetitive sequences during evolution (Kao et al., 2001), a process most likely driven by unequal translocation, pericentric inversion, and centric fusion and fission (Stebbins, 1971). Such differences in heterochromatin can be visualized on staining with the fluorochromes chromomycin A3 (CMA3) and 4,'6'-diamino-2phenylindole (DAPI; Pedrosa et al., 2001), because, as in most plant species, CMA3 binds to paracentromeric, early-replicating GC-rich
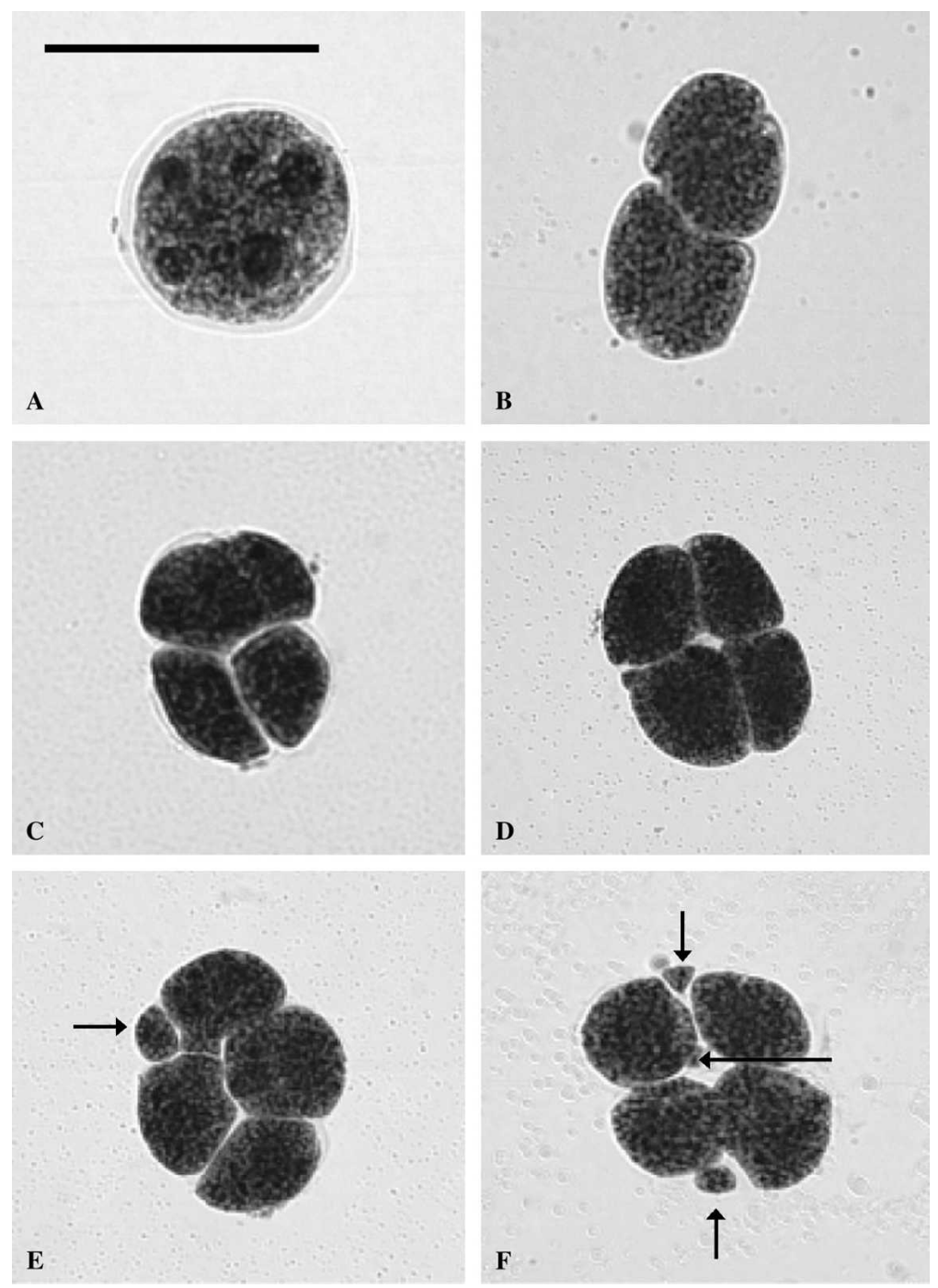

Fig. 1. Lactophenol-acid fuchsin staining of microspores in Doritaneopsis orchids. (A) Doritaenopsis Sogo Gem 'F752' monad; (B) Doritaenopsis Chian-Huey Red Rose 'F904' dyad; (C) Doritaenopsis Jiuhbao Red Rose triad; (D-F) Doritaenopsis Fucshia Princess 'KHM648' tetrad, tetrad plus micronuclei, and tetrad plus three micronuclei. Arrowheads point to micronuclei (scale bar $=$ $10 \mu \mathrm{m})$. 


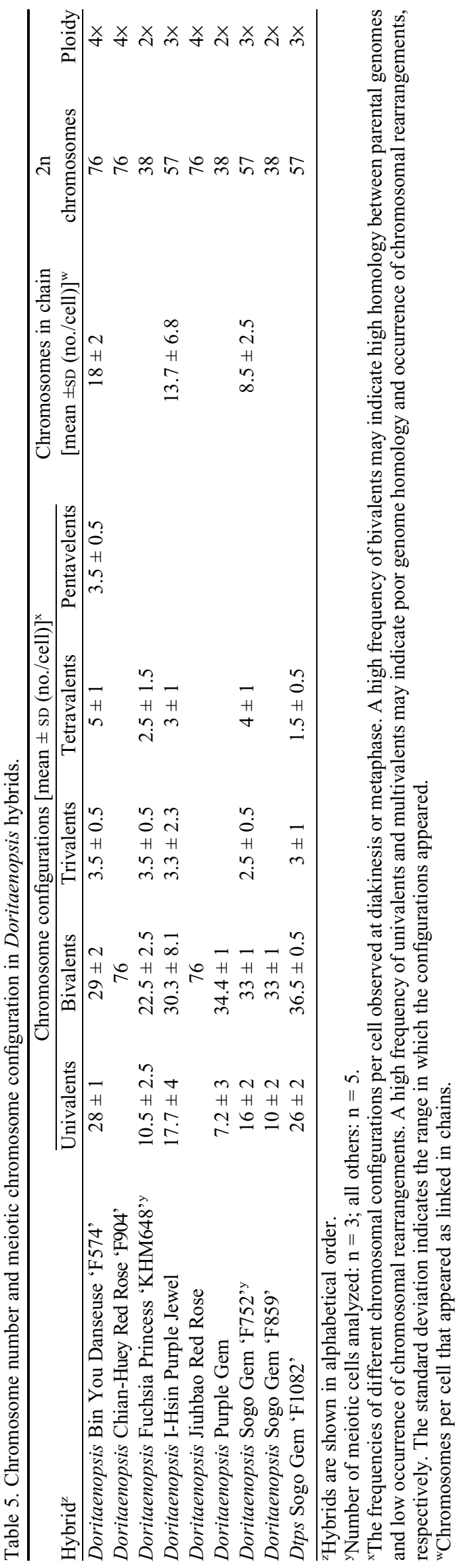

DNA, which gives an even staining through most of the euchromatic region, whereas DAPI binds to AT-rich, dense heterochromatic areas that replicate late in the S-phase (Belonogova et al., 2006; Sumner, 1991; Weiss-Schneeweiss et al., 2003). In this work, we used CMA3 and DAPI to visualize differences in chromosome structure within hybrids, as was previously reported in Phalaenopsis and Doritis species (Kao et al., 2001).

We aimed to investigate cytogenetic features, including chromosome number, chromosome pairing behavior, frequency of normal tetrads, and pollen viability, of several Doritaenopsis and Phalaenopsis hybrids and to relate that information to capsule set and overall crossing ability. Such information should assist future efforts to evaluate specific hybrids for use in breeding of seed-propagated cultivars or for line selection.

\section{Materials and Methods}

Plant material. Commercial hybrids of the artificial genus Doritaenopsis (crosses between Phalaenopsis and Doritis) were purchased from commercial nurseries and were cultivated in a greenhouse. Several hybrids were selected for being directly or indirectly derived from $D$. pulcherrima, with large chromosomes $(1-3 \mu \mathrm{m})$ and $P$. equestris, with minute chromosomes (less than $1 \mu \mathrm{m}$ ). Two Doritaenopsis hybrids (Doritaenopsis Chian-Huey Red Rose 'F904' and Doritaenopsis Jiuhbao Red Rose) were included for their ease of intercrossing (Table 1). P. equestris was used as a standard for comparison of pollen division patterns.

Pollen staining with fluorescein diacetate (FDA). Pollen viability analyzed by staining with FDA reveals cell membrane functionality (Pritchard, 1985). FDA (Fluka, Buchs, Switzerland) was dissolved at $0.5 \%(\mathrm{w} / \mathrm{v})$ in absolute acetone, $1: 49$ diluted in $10 \%$ sucrose solution. Fresh pollinia were collected from unopened full-size flower buds and were squashed onto clean slides with FDA. Slides containing the mixture of pollens and FDA were covered for at least $15 \mathrm{~min}$ to allow color to develop (Pritchard, 1985). The results were observed by use of a fluorescence microscope (Labophot-2; Nikon Corp., Tokyo) with a blue light filter. Cells exhibiting a bright yellow fluorescence were considered positively stained. At least three samples from different plants of the same clone were used. Still photographs were taken by use of a digital camera (E4500; Nikon).

SPORAD QUANTIFICATION IN POLLEN MOTHER CELLS (PMCs). To quantify the frequency of different types of sporads in hybrids, PMCs were stained with lactophenol-acid fuchsin solution (Lim et al., 2001). Pollinia from full-sized flower buds were fixed with $95 \%$ ethanol-glacial acetic acid (3:1 by vol) solution for $24 \mathrm{~h}$, hydrolyzed in $1 \mathrm{~N} \mathrm{HCl}$ for $1 \mathrm{~h}$ at $60^{\circ} \mathrm{C}$, rinsed three times with distilled water, and stained with lactophenolacid fuchsin solution containing $50 \mathrm{mg}$ of acid fuchsin, $5 \mathrm{~g}$ of phenol, $5 \mathrm{~mL}$ of lactic acid, $25 \mathrm{~mL}$ of glycerol, $10 \mathrm{~mL}$ of $95 \%$ ethanol, and $60 \mathrm{~mL}$ of distilled water. Material for observation was examined under an inverted phase-light microscope (Diaphot; Nikon). One thousand PMCs were categorized according to the number of sporads, especially tetrads, at the end of the division II stage, and at least three different plants were used for examination. Still pictures were taken by use of a digital camera (E4500; Nikon).

Chromosome SAMPLe PREPARATION AND ACETO-CARMine STAINING. To prepare samples of somatic and meiotic 
chromosomes, growing root tips were excised and anthers were taken from tightly closed flower buds at three-quarters of their final bud size (pachytene/metaphase-I stages; Table 1), as suggested by Dyer (1979). Root tips were pretreated with $2 \mathrm{~mm}$ 8-hydroxyquinoline (Sigma-Aldrich, St. Louis), $0.1 \%$ colchicine (Sigma-Aldrich), or paradichlorobenzenesaturated (Sigma-Aldrich) solution on a rotary shaker (100 rpm) for $5 \mathrm{~h}$ at 15 to $18{ }^{\circ} \mathrm{C}$, and were then fixed in $95 \%$ ethanol-propionic acid (3:1 by vol) for $48 \mathrm{~h}$ at $4{ }^{\circ} \mathrm{C}$. Samples were digested as suggested by Pedrosa et al. (2001) with $1 \%$ $(\mathrm{w} / \mathrm{v})$ cellulase (Sigma-Aldrich) and $0.5 \%(\mathrm{w} / \mathrm{v})$ pectinase (Fluka) in $10 \mathrm{~mm}$ citrate buffer. Digested samples were squashed in a droplet of $1 \%$ aceto-carmine on a microscope slide, covered with a coverslip, and analyzed under a light microscope (BX50; Olympus Corp., Tokyo) with a CCD camera (Pro150ES; Pixera Corp., Los Gatos, CA). Permanent slides were prepared by freezing with liquid nitrogen, air-dried, and then mounted in Entellan ${ }^{\circledR}$ (Merck KGaA, Darmstadt, Germany).

Estimation of CHROMosome number AND SIZE. Chromosome number counting and length measurement from digital images involved use of ImageJ software, a public domain image analysis application (U.S. National Institutes of Health, 2007). Final image adjustment involved use of Adobe Photoshop CS2 (Adobe Systems, San Jose, CA).

Fluorescent Staining. To observe fluorescent banding patterns in somatic chromosomes, chromosomal preparations were squashed and stained with $1 \%$ aceto-carmine on new, clean microscope slides. After the coverslips were removed with use of liquid nitrogen, the slides were air-dried and then flooded with $20 \mu \mathrm{L}$ of a solution containing CMA3 (Sigma-Aldrich). The CMA3 solution was prepared by dissolving $0.5 \mathrm{mg}$ of CMA3 per $\mathrm{mL}$ of $0.5 \times$ McIlvaine's buffer, consisting of 18 $\mathrm{mL}$ of $0.1 \mathrm{M}$ citric acid plus $82 \mathrm{~mL}$ of $0.2 \mathrm{M} \mathrm{Na}_{2} \mathrm{HPO}_{4}, \mathrm{pH} \mathrm{7}$, as described Friebe et al. (1996). To stain the samples with DAPI (Sigma-Aldrich), the coverslips were removed and the slides were immersed in distilled water to remove excess CMA3, and were then allowed to air dry. Once dry, the slides were flooded in DAPIcontaining solution, covered, and left in the dark at room temperature for 20 min. A working solution of DAPI was prepared by dissolving a stock solution of DAPI $\left(0.2 \mathrm{mg} \cdot \mathrm{mL}^{-1}\right)$ in McIlvaine's buffer (containing $5 \mathrm{~mm}$ $\mathrm{MgCl}_{2}$ ), at $1 \mu \mathrm{g}$ of DAPI solution per $999 \mu \mathrm{L}$ of buffer. Slides were observed within $24 \mathrm{~h}$ in the dark under a fluorescence microscope (Labophot-2; Nikon).

\section{Results}

SeEd SeT AND HYBRID homology. Crosses between Doritaenopsis hybrids consistently showed capsule setting and production of viable seeds largely between hybrids with similar chromosome number and size that involved little or no inversions and translocations, especially for crosses of Doritaenopsis Chian-Huey Red Rose 'F904' and Doritaenopsis Jiuhbao Red Rose (Table 2). Both hybrids contained small chromosomes. Crosses of Doritaenopsis Sogo Gem 'F859' (as pollen recipient), and Doritaenopsis Jiuhbao Red Rose and Doritaenopsis Chian-Huey Red Rose 'F904' (as pollen donors) succeeded in the first stages of fertilization (including development of pollen tubes; data not shown), but the resulting capsules aborted $80 \mathrm{~d}$ after pollination.

Physiological viability of POllen Cells. FDA staining of fully developed, fresh pollen masses from hybrids and species of Doritaenopsis and Phalaenopsis revealed that a high proportion of pollen cells of $P$. equestris $(70 \%)$ was stained, whereas most hybrid values ranged from $45 \%$ to $30 \%$, as in Doritaenopsis Chian-Huey 'F904' (45.6\%). Doritaenopsis Sogo Gem 'F752' showed the lowest value (20.7\%; Table 3).
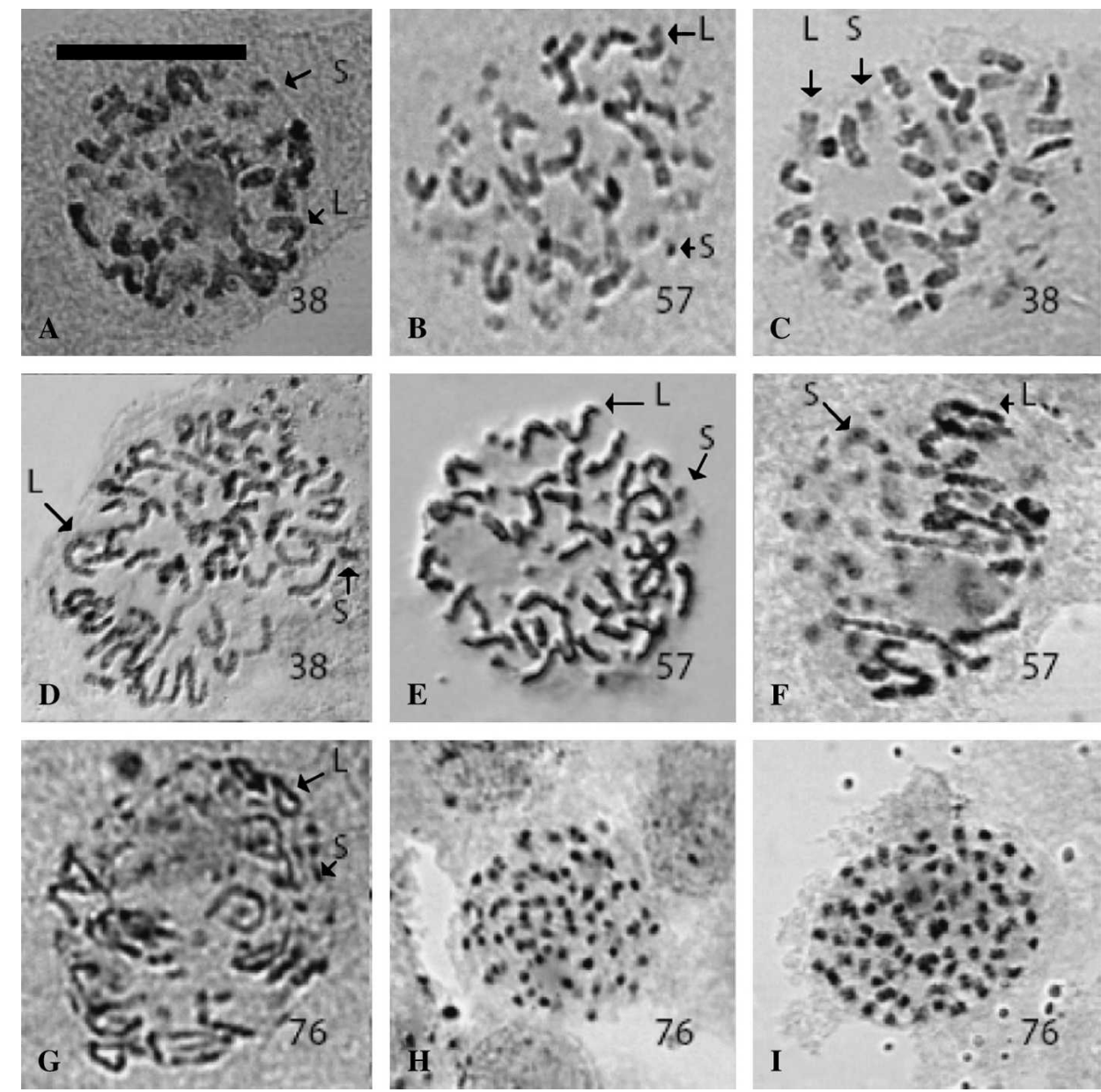

Fig. 2. Chromosome complement at somatic metaphase of Doritaenopsis orchids. (A) Doritaenopsis Sogo Gem 'F859'; (B) Doritaenopsis Sogo Gem '1082'; (C) Doritaenopsis Purple Gem; (D) Doritaenopsis Fuchsia Princess 'KHM648'; (E) Doritaenopsis I-Hsin Purple Jewel; (F) Doritaenopsis Sogo Gem 'F752'; (G) Doritaenopsis Bin You Danseuse 'F574'; (H) Doritaenopsis Chian-Huey Red Rose 'F904'; and (I) Doritaenopsis Jiuhbao Red Rose. Each picture displays the number of chromosomes. Arrowheads point to (L) large and (S) small chromosomes, except in (H) and (I) where all chromosomes are small (scale bar $=10 \mu \mathrm{m})$. 
FREQUENCY OF TETRADS IN MATURE POLLINIA. Samples of mature pollinia were stained with lactophenol-acid fuchsin to quantify the frequency of tetrads per thousand pollen cells, taking tetrad formation as an indicator of even assortment of chromosomes. In $P$. equestris, Doritaenopsis Chian-Huey Red Rose 'F904', and Doritaenopsis Jiuhbao Red Rose, most PMCs divided into tetrads $(928,835$, and 607 cells of 1000 , respectively). The opposite occurred in hybrids Doritaenopsis Bin You Danseuse 'F574' and Doritaenopsis Sogo Gem 'F859', where less than 100 of PMCs divided into tetrads. In both hybrids, most of the other PMCs divided irregularly into sporads with a varying number of micronuclei (Table 4 and Fig. 1).

Chromosome NUMBER AND PAIRING BEHAVIOR DURING MEIOSIS. Results from chromosome counts in the somatic tissue of Doritaenopsis and Phalaenopsis showed sharp differences in ploidy (Table 5 and Fig. 2). Chromosome constitutions ranged from diploidy $(2 \times)$ for Doritaenopsis Sogo Gem 'F859', Doritaenopsis Purple Gem, and Doritaenopsis Fuchsia Princess 'KHM648'; triploidy $(3 \times)$ for Doritaenopsis Sogo Gem 'F1082', Doritaenopsis Sogo Gem 'F752', and Doritaenopsis I-Hsin Purple Jewel; and tetraploidy $(4 \times)$ for hybrids Doritaenopsis Jiuhbao Red Rose, Doritaenopsis Chian-Huey Red Rose 'F904', and Doritaenopsis Bin You Danseuse 'F574'.

Many hybrids showed chromosome configurations such as trivalents, tetravalents, and multivalents at metaphase I (Table 5 and Fig. 3), as well as uneven division of PMCs (Fig. 4) and chromosomal bridges (Fig. 5). Three types of hybrids based on observed chromosome configurations at metaphase I and on the meiotic disorders mentioned above were distinguished. In type one, chromosomes were completely or almost completely homologous, as evidenced by most chromosomes paired as bivalents. Type one hybrids include Doritaenopsis Jiuhbao Red Rose (4×), Doritaenopsis Chian-Huey Red Rose 'F904' (4×), and, to some extent, Doritaenopsis Purple Gem $(2 \times)$ (Table 4). In type two hybrids, chromosomes had partial or low homology, with most chromosomes configured as univalents and, in some cases, tetravalents (Fig. 4); lagging chromosomes were common at anaphase I and the prevalence of
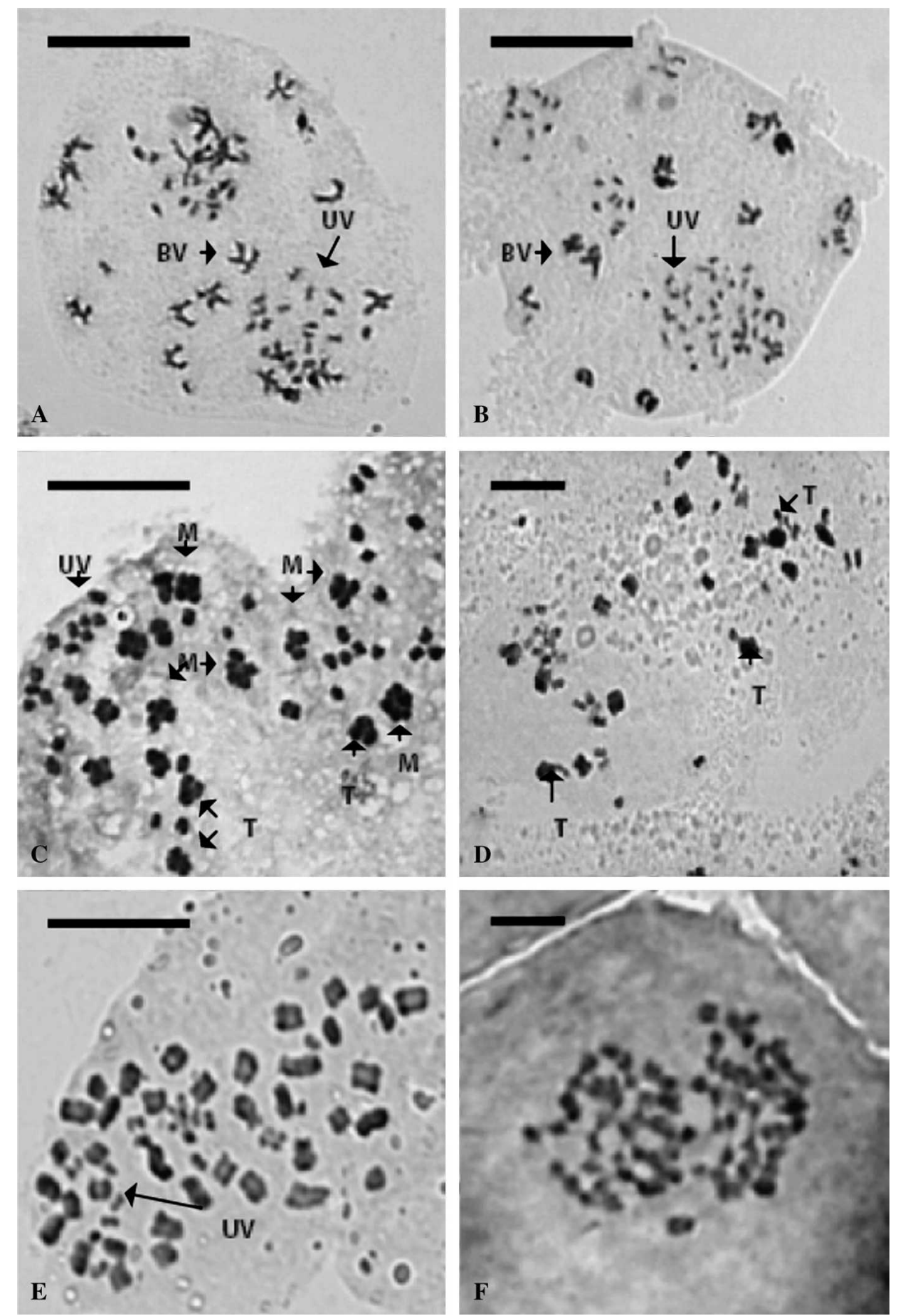

Fig. 3. Meiotic chromosome configurations in several Doritaenopsis hybrids by aceto-carmine staining. (A) Doritaenopsis Sogo Gem 'F859' at diakinesis; (B) Doritaenopsis Bin You Danseuse 'F574' at diakinesis; (C) Doritaenopsis I-Hsin Purple Jewel at metaphase; (D) Doritaenopsis Sogo Gem 'F1082' at metaphase; (E) Doritaenopsis Purple Gem at metaphase; and (F) Doritaenopsis Jiuhbao Red Rose at anaphase (BV = bivalent; $\mathrm{M}=$ multivalent; $\mathrm{T}=$ trivalent; $\mathrm{UV}=$ univalent; scale bar $=10 \mu \mathrm{m}$ ). micronucleated meiocytes was high (up to 10 in a cell; data not shown). Type two hybrids include Doritaenopsis Sogo Gem 'F859' (2×) and Doritaenopsis Bin You Danseuse 'F574' (4×). In type three hybrids, chromosomes showed aberrant configurations such as tetravalents and multivalents (chains) during meiosis, inversion loops, and translocation junctions at pachytene (Fig. 6), as well as chromosomal bridges with fragments 

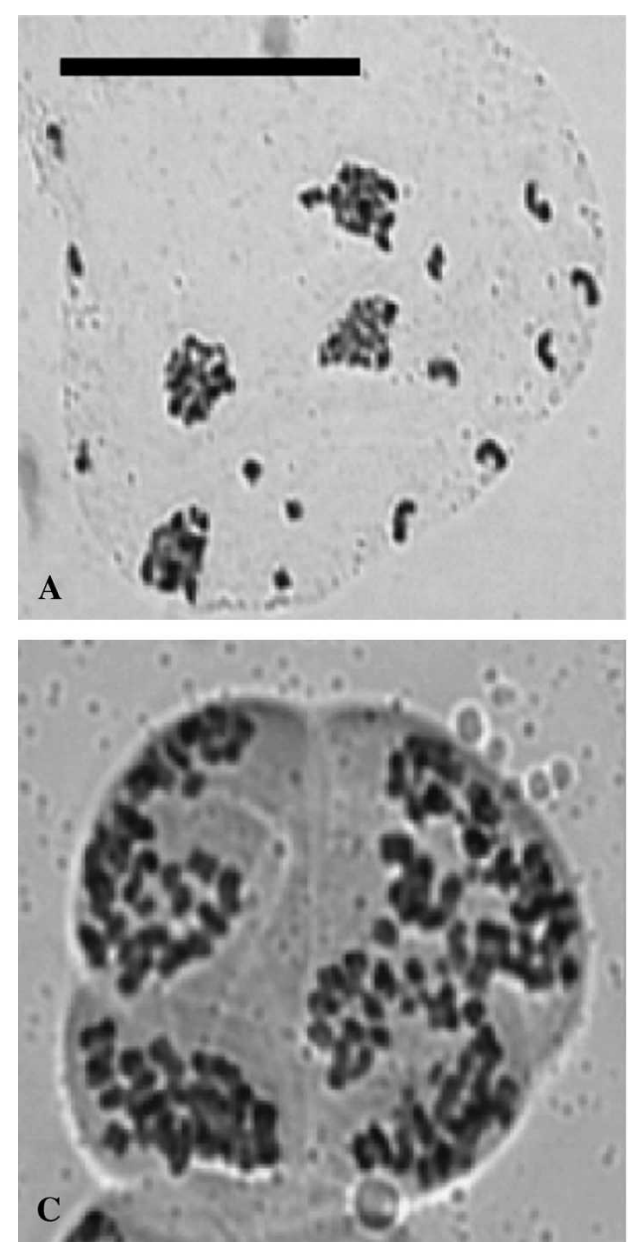

B
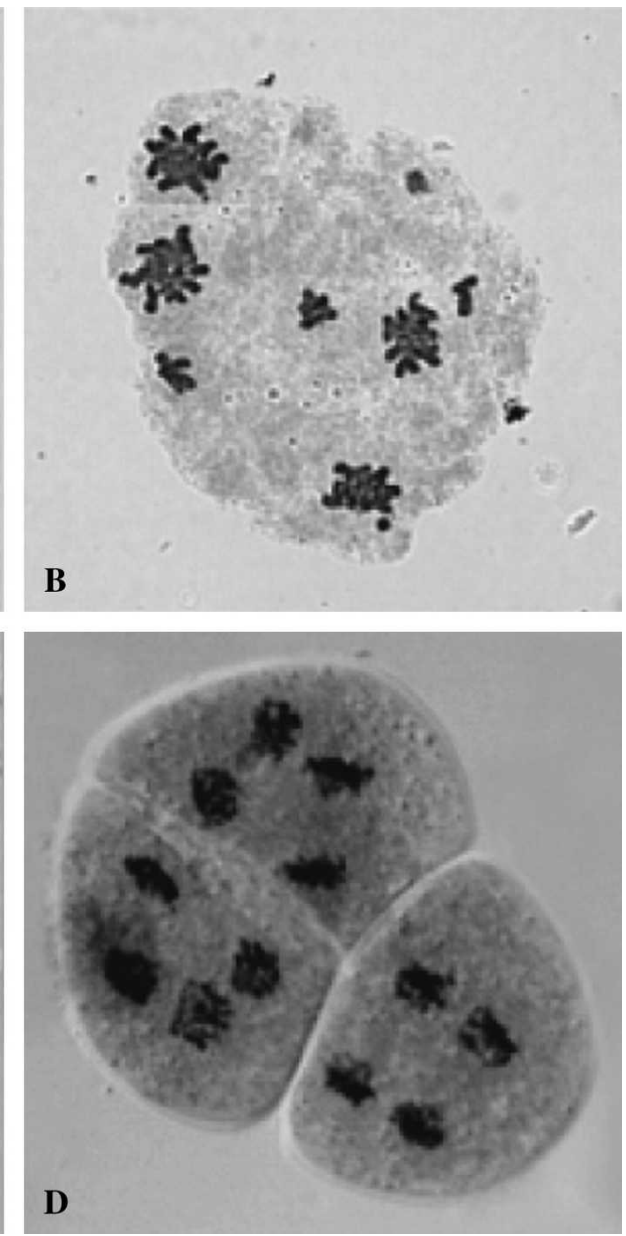

Fig. 4. Division patterns of pollen mother cells (PMCs) in Doritaenopsis hybrids by aceto-carmine staining. (A) Doritaenopsis Sogo Gem 'F859' at late anaphase II; (B) Doritaenopsis Sogo Gem 'F752' at late anaphase II; (C) Doritaenopsis Fuchsia Princess 'KHM 648' at early anaphase II; and (D) Doritaenopsis Chian-Huey Red Rose 'F904' PMCs at metaphase (scale bar $=10 \mu \mathrm{m})$.
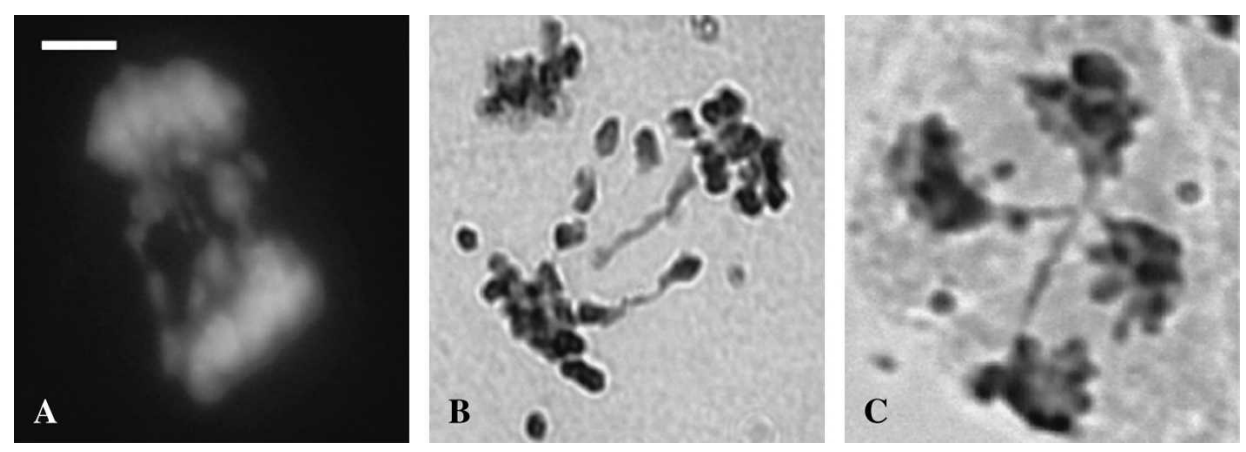

Fig. 5. Meiotic chromosome bridges in Doritaenopsis orchids. (A) Doritaenopsis Fuchsia Princess 'KHM648'; (B) Doritaenopsis Sogo Gem 'F859'; and (C) Doritaenopsis Sogo Gem 'F752.' (A) stained by 4,'6'-diamino-2phenylindole and $(\mathbf{B}$ and $\mathbf{C})$ stained by aceto-carmine (scale bar $=10 \mu \mathrm{m})$. at mitotic metaphase by centromere position or secondary constrictions was difficult. We classified the karyotype of each hybrid into a unimodal or bimodal arrangement on the basis of the relative size of chromosomes observed at somatic metaphase, with most hybrids having bimodal karyotypes, except for Doritaenopsis Chian-Huey Red Rose 'F904'and Doritaenopsis Jiuhbao Red Rose (Table 6). Additionally, we rated the formation of dicentric bridges at anaphase and the formation of micronuclei at metaphase on a scale ranging from absent $(-)$ to very frequent $(+++)$, with both phenomena overlapping in Doritaenopsis Sogo Gem 'F752', Doritaenopsis Sogo Gem 'F859', Doritaenopsis Sogo Gem 'F1082', and Doritaenopsis Fuchsia Princess 'KHM 648' (Table 6).

Visualization OF HETEROChromatin Distribution. Staining with fluorochromes CMA3 and DAPI was used to visualize heterochromatin distribution on chromosomes at somatic prometaphase of Doritaenopsis Purple Gem (Fig. 8). Cells from Doritaenopsis Purple Gem were amenable to fluorescent banding because of a seemingly high mitotic index (a character specific to this hybrid) and relatively large chromosomes $(\approx 3 \mu \mathrm{m})$. DAPI staining showed strong blue fluorescence at chromosomal ends and in small intercalary areas of larger chromosomes. However, no such fluorescence was detected around centromeres. Smaller chromosomes displayed weak fluorescence by DAPI staining but remained stainable by CMA3. In comparison with acetocarmine staining, DAPI staining was useful in visualizing abnormal phenomena such as bridges, fragments, and lagging chromosomes in meiotic samples of Doritaenopsis Fuchsia Princess 'KHM648' (Fig. 7).

\section{Discussion}

The chromosomal configurations at anaphase (Fig. 7). Type three hybrids showed more or less serious overall micronucleation. Type three hybrids include Doritaenopsis Sogo Gem 'F1082' (3×), Doritaenopsis Sogo Gem 'F752' (3×), Doritaenopsis Fuchsia Princess 'KHM648' $(2 \times)$, and Doritaenopsis I-Hsin Purple Jewel (3×).

Chromosome size. Because of the small size of the chromosomes (1-3 $\mu \mathrm{m})$, identifying individual chromosomes observed at meiotic metaphase in orchid hybrids could reflect incompatibility caused by genomic divergence between their progenitors (Arends, 1970). Incompatible chromosomes fail to synapse at pachytene; consequently, no chiasmata are formed between them, which results in univalents observed at metaphase. Univalents may not align properly to the metaphase plate and thus segregate incorrectly at anaphase I (Ma, 2006). As a 


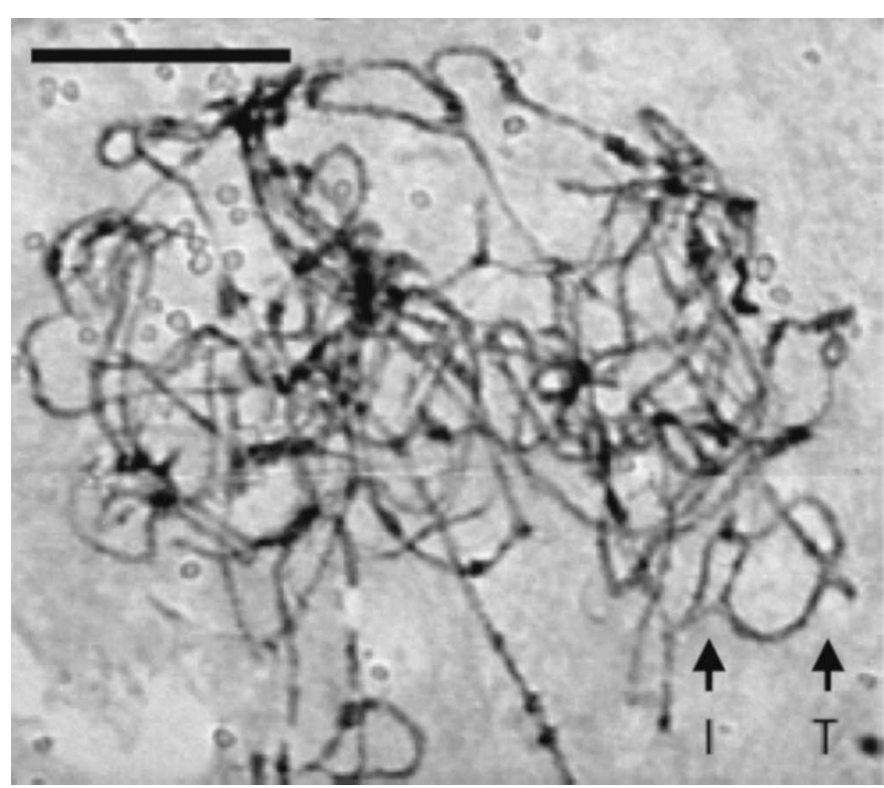

Fig. 6. Inverted and translocated pachytene chromosomes in Doritaenopsis Fucshia Princess 'KHM648' [I = inversion loop; $\mathrm{T}=$ translocation junction (see arrowheads), scale bar $=10 \mu \mathrm{m}]$.

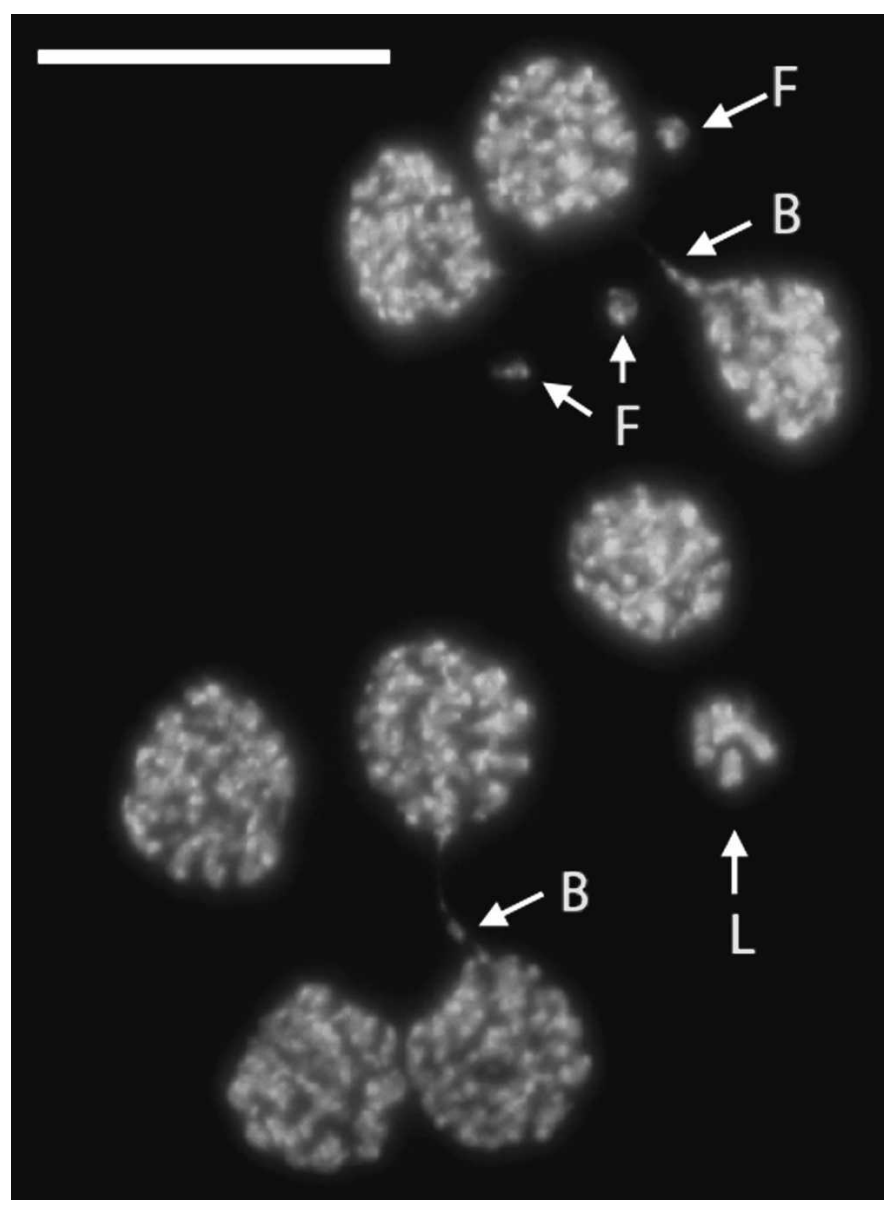

Fig. 7. Meiotic chromosome disorders in cells of Doritaenopsis Fuchsia Princess 'KHM648' stained with 4,'6'-diamino-2-phenylindole. Note: (F) a chromosomal fragment, (B) a chromosome bridge, (L) and lagging chromosomes, possibly forming a micronucleus (scale bar $=10 \mu \mathrm{m}$ ). result, meiotic products with unbalanced chromosome constitutions may affect the functions and development of gametes (Singh, 2003). Additionally, partial homology between parent genomes in diploid hybrids and aneuploids may cause chromosomes to pair as trivalents (Swanson et al., 1981). In Arabidopsis thaliana (L.) Heynh., mutants of Zip4/Sp022 genes showed unpaired univalent chromosomes and subsequent poor seed set after fertilization (Chelysheva et al., 2007). We observed a similar association of univalents and other nonbivalents with low or no fertility in Doritaenopsis hybrids.

The bridges and fragments we observed in meiotic anaphase I in Doritaenopsis Sogo Gem 'F1089', Doritaenopsis Bin You Danseuse 'F574', Doritaenopsis Sogo Gem 'F752' (3×), Doritaenopsis Fuchsia Princess 'KHM648', and Doritaenopsis I-Hsin Purple Jewel indicate that a paracentric inversion contributes to the differentiation of these hybrid genomes. Reciprocal translocations could also be frequent in Doritaenopsis Bin You Danseuse 'F574' and Doritaenopsis I-Hsin Purple Jewel and might explain the high frequency of multivalents. Interestingly, all hybrids with inversions or translocations have D. pulcherrima as a first- or second-generation female parent, whereas Doritaenopsis Chian-Huey Red Rose 'F904' and Doritaenopsis Jiuhbao Red Rose do not, nor do they possess any $D$. pulcherrima-like chromosomes.

In general, meiotic aberrations such as bridges/fragments, asymmetric segregation, heteromorphic bivalents, and karyotype asymmetry might result from chromosome structure mutations (Wang and Zhang, 2007). According to Levin (2002), each novel translocation and inversion initially is rare and occurs in a heterozygous condition, which is a liability because heterozygous plants typically have $50 \%$ fertility. Translocations are reportedly more common than inversions with large number of chromosomes and, in addition to altering end arrangements, may lead to loss of chromosomes (Levin, 2002).

A previous study of the distribution of heterochromatin in Phalaenopsis and Doritis (Kao et al., 2001) showed large chromosomes with a prevalence of large terminal heterochromatic blocks (common in D. pulcherrima), whereas small chromosomes (common in genus Phalaenopsis section Phalaenopsis) seemed to contain heterochromatin beyond the resolution capacity of cytological detection. DAPI and CMA3 staining of somatic prometaphase chromosomes of Doritaenopsis Purple Gem allowed for visualization of clusters of terminal, AT-rich heterochromatin in all large chromosomes, whereas small chromosomes were stained in their entirety by CMA3 (e.g., euchromatic) (Fig. 8). This finding may suggest the existence of two mechanisms influencing chromosome pairing: 1) evolutionary differences in heterochromatin distribution and content may create incompatible "best-fit" chromosomal landscapes that make pairing difficult, and 2) large chromosomes with high heterochromatin content seem more prone to breakage events (Swanson et al., 1981). Thus, hybrids with large chromosomes might undergo high rates of rearrangements that decrease homology (Levin, 2002; Swanson et al., 1981), a fitting scenario for Doritaenopsis Sogo Gem 'F752', 'F859', 'F1082', Doritaenopsis Fuchsia Princess 'KHM 648', and Doritaenopsis I-Hsin Purple Jewel.

Hybrids with chromosomal aberrations or micronucleation, such as in Doritaenopsis Sogo Gem 'F859' and Doritaenopsis Sogo Gem 'F1082', tended to show higher intensity of fluorescence (on FDA staining) than hybrids with otherwise fit pollen cells, such as Doritaenopsis Jiuhbao Red Rose. This 
Table 6. Length variation and meiotic aberrations in metaphase chromosomes of several Doritaenopsis hybrids. ${ }^{\mathrm{z}}$

\begin{tabular}{|c|c|c|c|c|}
\hline Hybrid $^{\mathrm{z}}$ & $\begin{array}{c}\text { Mode of length } \\
\text { variation }\end{array}$ & $\begin{array}{l}\text { Chromosome } \\
\text { size }(\mathrm{L} \text { or } \mathrm{S})^{\mathrm{y}}\end{array}$ & $\begin{array}{c}\text { Dicentric } \\
\text { bridges } \\
(- \text { to }+++ \text { scale })^{x}\end{array}$ & $\begin{array}{c}\text { Formation of } \\
\text { micronuclei } \\
(- \text { to }+++ \text { scale })^{\mathrm{w}} \\
\end{array}$ \\
\hline$\overline{\text { Doritaenopsis Bin You Danseuse 'F574' }}$ & Bimodal & $24 \mathrm{~L}+52 \mathrm{~S}$ & + & +++ \\
\hline Doritaenopsis Fuchsia Princess 'KHM648' & Bimodal & $24 \mathrm{~L}+14 \mathrm{~S}$ & +++ & ++ \\
\hline Doritaenopsis I-Hsin Purple Jewel & Bimodal & $29 \mathrm{~L}+28 \mathrm{~S}$ & + & +++ \\
\hline Doritaenopsis Jiuhbao Red Rose & Unimodal & all short & - & - \\
\hline Doritaenopsis Sogo Gem 'F752' & Bimodal & $35 \mathrm{~L}+22 \mathrm{~S}$ & +++ & + \\
\hline Doritaenopsis Sogo Gem 'F859' & Bimodal & $18 \mathrm{~L}+20 \mathrm{~S}$ & ++ & +++ \\
\hline Doritaenopsis Sogo Gem 'F1082' & Bimodal & $22 \mathrm{~L}+35 \mathrm{~S}$ & +++ & ++ \\
\hline
\end{tabular}

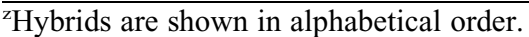

${ }^{\mathrm{y}} \mathrm{L}=$ long chromosomes $(1-3 \mu \mathrm{m}) ; \mathrm{S}=$ short chromosome (less than $\left.1 \mu \mathrm{m}\right)$.

${ }^{x}$ Observed frequency of dicentric bridges at anaphase per cell: absent $(-)$, occasional $(+)$, frequent $(++)$, very frequent $(+++)$.

${ }^{\mathrm{w}}$ Observed frequency of formation of micronuclei per cell: absent $(-)$, occasional $(+)$, frequent $(++)$, very frequent $(+++)$.

pattern is apparently at odds with the idea that chromosomal heterozygotes have reduced fertility. In cells with an intact plasma membrane, FDA can freely enter living cells and is hydrolyzed by esterase enzymes to give fluorescein; cells accumulate fluorescein and become brightly fluorescent (Pritchard, 1985). A high percentage of cells from hybrids with serious chromosomal deficiencies fluoresced may not be a contradictory result because abnormal plant meiocytes (e.g., microspores) do not undergo programmed cell death as do abnormal animal cells (Ma, 2006). Perhaps a better indication of pollen fitness is the dominant division pattern of PMCs during division II, as seen by staining with lactophenol-acid fuchsin (Table 3). In this case, hybrids with a low frequency of tetrads also tended to show asymmetric segregation, chromosomal aberrations, and poor pollen viability, and hybrids with high frequency of tetrads show the reverse.

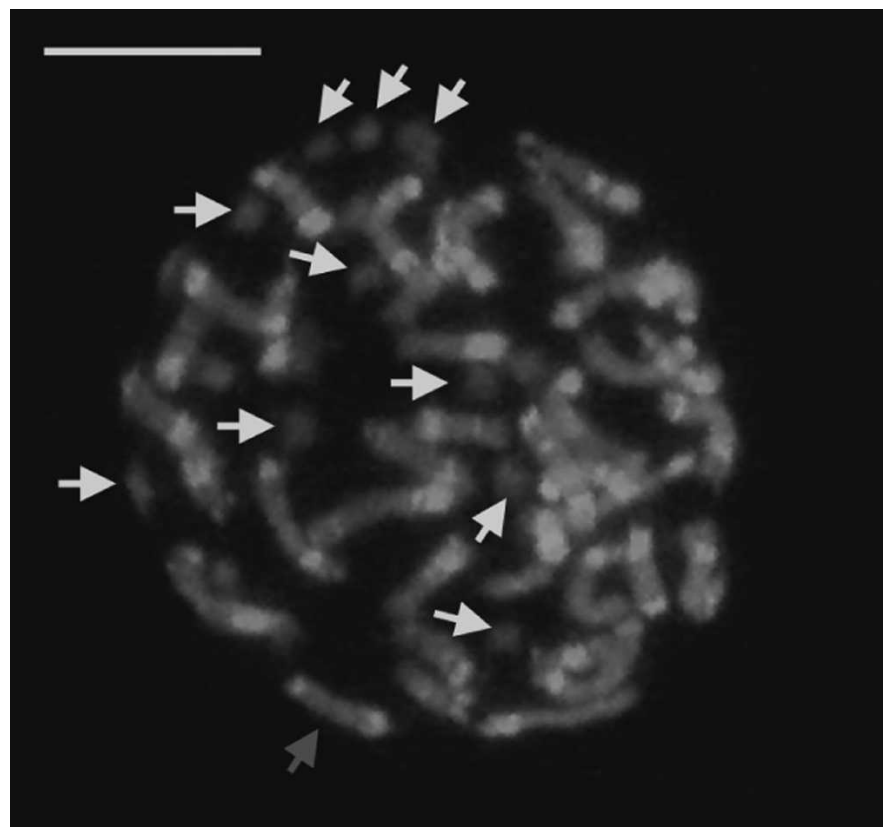

Fig. 8. 4,'6'-Diamino-2-phenylindole/chromomycin A3-stained somatic prometaphase chromosomes of Doritaenopsis Purple Gem. Note the prevalence of terminal blocks of heterochromatin (blue arrows) in large chromosomes and the lack of heterochromatin in smaller chromosomes (white arrows). Scale bar $=10 \mu \mathrm{m}$.
Our pollination results (Table 2) seem to indicate successful seed set in reciprocal crosses of hybrids with normal cell division patterns, whereas crosses involving aberrant pollen cells led to low seed yield, capsule abortion, or no production of capsules. Formation of irregular sporads had been previously reported in interspecific hybrids of Phalaenopsis (Arends, 1970; Shindo and Kamemoto, 1963), but inversions or translocations were not observed and pollen viability was not investigated. In our study, Doritaenopsis hybrids with poor chromosome pairing commonly showed failure of seed setting after cross pollination, a result similar to that reported by Arends (1970). However, the finding of inversions and translocations implies the existence of additional hybridization barriers in Doritaenopsis not before considered. Abnormal cytological behavior of the PMCs of an autotetraploid Vaccinium elliottii Chapm. also resulted with reduced pollen viability (Dweikat and Lyrene, 1991; Vorsa and Ballington, 1991). This suggests the widespread occurrence of abnormal meiotic behavior and pollen viability among plants.

For breeders, the existence of chromosomal rearrangements such as inversions and translocations in parental genomes implies that chromosome doubling in hybrids may not restore fertility (Kamstra et al., 1999); thus, careful screening of cultivars before breeding is necessary. Alternatively, the search for unreduced gametes and subsequent embryo rescue may offer the opportunity of partial fertility in cross-hybridization of Doritaenopsis, as implicated in other crops (Lyrene, 1991; Sugiura et al., 2000; Widrlechner et al., 1982).

\section{Literature Cited}

Arends, J.C. 1970. Cytological observations on genome homology in eight interspecific hybrids of Phalaenopsis. Genetica 41:88-100. Armstrong, S.J. and G.H. Jones. 2003. Meiotic cytology and chromosome behaviour in wild-type Arabidopsis thaliana. J. Expt. Bot. 54:1-10.

Armstrong, S.J., F. Christopher, H. Franklin, and G.H. Jones. 2001. Nucleolus-associated telomere clustering and pairing precede meiotic chromosome synapsis in Arabidopsis thaliana. J. Cell Sci. 114:4207-4217.

Belonogova, N.M., T.V. Karamysheva, L.S. Biltueva, E.A. Perepelov, J.M. Minina, A.V. Polyakov, N.S. Zhdanova, N.B. Rubtsov, J.B. Searle, and P.M. Borodin. 2006. Identification of all pachytene bivalents in the common shrew using DAPI-staining of synaptonemal complex spreads. Chromosome Res. 14:673-679. 
Chelysheva, L., G. Gendrot, D. Vezon, M.P. Doutriaux, and R. Mercier. 2007. Zip4/Spo22 is required for class I CO formation but not for synapsis completion in Arabidopsis thaliana. PLoS Genet. 3(5):e83, doi: 10.1371/journal.pgen.0030083.

Dweikat, I.M. and P.M. Lyrene. 1991. Induced tetraploidy in a Vaccinium elliottii facilitates crossing with cultivated highbush blueberry. J. Amer. Soc. Hort. Sci. 116:1063-1066.

Dyer, A.F. 1979. Investigating chromosomes. Edward Arnold Publishers, London.

Friebe, K., T.R. Endo, and B.S. Gill. 1996. Plant chromosomes at mitosis, p. 123-154. In: K. Fukui and S. Nakayama (eds.). Plant chromosomes. CRC Press, Boca Raton, FL.

Hiraoka, Y. 1998. Meiotic telomeres: A matchmaker for homologous chromosomes. Genes Cells 3:405-413.

Huisinga, K.L., B. Brower-Toland, and S.C.R. Elgin. 2006. The contradictory definitions of heterochromatin: Transcription and silencing. Chromosoma 115:110-122.

Kamemoto, H., T. D’Amore, and A. Kuehnle. 1999. Breeding Dendrobium orchids in Hawaii. 1st ed. University of Hawaii Press, Honolulu.

Kamstra, S.A., M.S. Ramanna, M.J. De Jeu, A.G.J. Kuipers, and E. Jacobsen. 1999. Homoeologous chromosome pairing in the distant hybrid Alstroemeria aurea $\times$ A. inodora and the genome composition of its backcross derivatives determined by fluorescence in situ hybridization with species-specific probes. Heredity 82:69-78.

Kao, Y.Y., S.B. Chang, T.Y. Lin, C.H. Hsieh, Y.H. Chen, W.H. Chen, and C.C. Chen. 2001. Differential accumulation of heterochromatin as a cause for karyotype variation in Phalaenopsis orchids. Ann. Bot. (Lond.) 873:387-395.

Levin, D. 2002. The role of chromosomal change in plant evolution. Oxford University Press, New York.

Lim, K.B., M.S. Ramanna, J.H. de Jong, E. Jacobsen, and J.M. van Tuyl. 2001. Indeterminate meiotic restitution (IMR): A novel type of meiotic nuclear restitution mechanism detected in interspecific lily hybrids by GISH. Theor. Appl. Genet. 103:219-230.

Lin, S., H.C. Lee, W.H. Chen, C.C. Chen, Y.Y. Kao, Y.M. Fu, Y.H. Chen, and T.Y. Lin. 2001. Nuclear DNA contents of Phalaenopsis sp. and Doritis pulcherrima. J. Amer. Soc. Hort. Sci. 126:195-199.

Lyrene, P.M. 1991. Fertile derivatives from sparkleberry $\times$ blueberry crosses. J. Amer. Soc. Hort. Sci. 116:899-902.

Ma, H. 2006. A molecular portrait of Arabidopsis meiosis. In: C.R. Somerville and E.M. Meyerowitz (eds.). The arabidopsis book. 5 May 2007. <www.aspb.org/publications/arabidopsis>.
Pedrosa, A., M.F. Jantsch, E.A. Moscone, P.F. Ambros, and D. Schweizer. 2001. Characterisation of pericentromeric and sticky intercalary heterochromatin in Ornithogalum longibracteatum (Hyacinthaceae). Chromosoma 110:203-213.

Pritchard, H.W. 1985. Determination of orchid seed viability using fluorescein diacetate. Plant Cell Environ. 8:727-730.

Royal Horticultural Society. 2007. The international orchid register: Orchid register search page. 5 May 2007. <http://www.rhs.org.uk/ plants/registerpages/orchidsearch.asp $>$.

Schwarzacher, T. 2003. Meiosis, recombination and chromosomes: A review of gene isolation and fluorescent in situ hybridization data in plants. J. Expt. Bot. 54:11-23.

Singh, R.J. 2003. Plant cytogenetics. 2nd ed. CRC Press, Boca Raton, FL.

Singh, R.J. and T. Hymowitz. 1987. Intersubgeneric crossability in the genus Glycine Willd. Plant Breed. 98:171-173.

Shindo, K. and H. Kamemoto. 1963. Karyotype analysis of some species of Phalaenopsis. Cytologia (Tokyo) 28:390-398.

Stebbins, G.L. 1971. Chromosomal evolution in higher plants. 1st ed. Edward Arnold Publishers, London.

Sugiura, A., T. Ohkuma, Y.A. Choi, R. Tao, and M. Tamura. 2000. Production of nonaploid $(2 \mathrm{n}=9 \times)$ Japanese persimmons (Diospyros kaki) by pollination with unreduced $(2 \mathrm{n}=6 \times)$ pollen and embryo rescue culture. J. Amer. Soc. Hort. Sci. 125:609-614.

Sumner, A.T. 1991. Chromosome banding. 1st ed. Unwin Hyman, London.

Swanson, C.P., T. Merz, and W.J. Young. 1981. Cytogenetics: The chromosome in division, inheritance, and evolution. 2nd ed. Prentice-Hall, Boston.

U.S. National Institutes of Health. 2007. ImageJ. 6 Oct. 2007. <http:// rsb.info.nih.gov/ij/>.

Vorsa, N. and J.R. Ballington. 1991. Fertility of triploid highbush blueberry. J. Amer. Soc. Hort. Sci. 116:336-341.

Wang, S.Q. and D. Zhang. 2007. Chromosomal inversion heterozygosity in Paeonia intermedia (Paeoniaceae). Plant Sci. 172:380392.

Weiss-Schneeweiss, H., T.F. Stuessy, S. Siljak-Yakovlev, C.M. Baeza, and J. Parker. 2003. Karyotype evolution in South American species of Hypochaeris (Asteraceae, Lactuceae). Plant Syst. Evol. 241:171184.

Widrlechner, M., H. Pellett, and P. Ascher. 1982. Unreduced gametes in azalea hybrids: A possible breeding method for using promising azaleas of low fertility. J. Amer. Rhododendron Soc. 36:98-101. 